\title{
EVALUASI PAKAN SAPI JANTAN DALAM KEGIATAN PEMBIBITAN SAPI BALI (Bos sondaicus)
}

\author{
Feeding Evaluation of Bali Bulls' Breeding (Bos sondaicus) \\ Reni Kurniawati ${ }^{1)}$, Putu Novia Gariri ${ }^{2)}$, Mei Via Safitri ${ }^{2}$, Maskur $^{2)}$ Nurkholis $^{1)}$ dan Suluh Nusantoro ${ }^{1)}$ \\ 1) Dosen Jurusan Peternakan, Program Studi Produksi Ternak, Politeknik Negeri Jember. Jl. Mastrip 164 \\ Jember 68121 \\ 2) Staf Balai Pembibitan Ternak Unggul Dan Hijauan Pakan Ternak Jl. Gurita III, Pegok, Sesetan, Kec. \\ Denpasar Sel., Kota Denpasar, Bali 80223 \\ Email: suluh@polije.ac.id
}

\begin{abstract}
ABSTRAK
Sapi Bali (Bos sondaicus) merupakan salah satu ternak lokal yang berpotensi untuk dikembangkan sebagai penghasil daging maupun dalam kegiatan pembibitan. Suatu studi lapang dilakukan untuk menilai pemberian pakan terhadap performa sapi Bali (Bos sondaicus) jantan pada pemeliharaan di instalasi pembibitan BPTU - HPT Bali. Pengamatan dilakukan terhadap sembilan ekor sapi Bali jantan berumur 1,6 - 2 tahun dengan rata-rata bobot awal 395,00 \pm 38,38 kg. Sapi Bali yang dipelihara selama 60 hari mengkonsumsi pakan sebesar $5,98 \mathrm{~kg}$ BK/ekor/hari, asupan protein kasar 0,81 kg/ekor/hari serta TDN 3,8 kg/ekor/hari. Hasil evaluasi menunjukkan bahwa performa sapi berada dalam kisaran yang normal dan baik untuk pembibitan sapi Bali.
\end{abstract}

Kata kunci: Pembibitan, performa, praktis, sapi Bali

How to Cite:

Kurniawati, R., Gariri, P.N., Safitri, M.V., Maskur., Nurkholis., \& Nusantoro, S. (2019). Evaluasi Pakan Sapi Jantan dalam Kegiatan Pembibitan Sapi Bali (Bos sondaicus). Jurnal Nutrisi Ternak Tropis 2 (2) 47-50
*Corresponding author:

Suluh Nusantoro

Email: suluh@polije.ac.id

Program Studi Produksi Ternak, Politeknik Negeri

Jember. Jl. Mastrip 164 Jember 68121 


\section{ABSTRACT}

Bali cattle (Bos sondaicus) is one of Indonesian native livestock that potentially can be reared as beef production as well as breeding. Field research was conducted to evaluate feeding practice on performance of male Bali cattle at breeding installation of BPTU - HPT Bali. The amount of nine male with average initial body weight $395.00 \pm 38.38 \mathrm{~kg}$, ranging from 1.6 - 2.2 years was observed. During 60 days, Dry matter feed intake steer was 5.98 $\mathrm{kg} / \mathrm{cattle} /$ day, $0.81 \mathrm{~kg} / \mathrm{cattle} /$ day protein intake and $3.8 \mathrm{~kg} / \mathrm{cattle} /$ day $\mathrm{TDN}$. The result of evaluation showed that performance was appropriate for breeding.

Keywords: Breeding, performance, practical feeding, Bali steer

\section{PENDAHULUAN}

Sapi Bali (Bos sondaicus) merupakan ternak lokal yang telah tersebar ke beberapa wilayah Indonesia dan dikembangkan sebagai ternak potong karena memiliki keunggulan, diantaranya adaptif terhadap lingkungan serta mutu pakan yang rendah atau kasar (Tonbensi, dkk., 2009). Sapi Bali juga memiliki penampilan reproduksi yang baik dan angka kematian rendah (Siswanto, dkk., 2013). Populasi sapi terbanyak terdapat di Provinsi Bali sebesar 655.026 ekor diikuti oleh Sulawesi Selatan 626.954 ekor, NTB 546.114 ekor, dan NTT 504.954 ekor (Astiti, 2018).

Kegiatan pembibitan merupakan salah satu faktor pendukung kesinambungan usaha penggemukan sapi potong. Sapi Bali jantan dipertahankan dalam performa yang baik agar bisa berperan sebagai pejantan berkualitas. Untuk itu, upaya yang dilakukan di instalasi pembibitan sapi adalah melalui pemberian pakan berkualitas yang sesuai dengam kebutuhan reproduksi. Di samping pengaruh faktor genetik, performa reproduksi dipengaruhi juga oleh nutrisi. Misanya, pada kondisi kekurangan nutrisi, ternak mengalami penurunan bobot badan, kondisi tubuh, dan penundaan pubertas (Bindari et al, 2013)

Berbagai informasi ilmiah tentang sapi Bali di berbagai daerah telah dilakukan. Kajian yang dilakukan meliputi aspek performa produksi dan reproduksi sapi peternak (Tonbensi, dkk., 2009; Tahuk dan Dethan, 2010;). Selain aspek performa, riset pertumbuhan alometri sapi Bali juga dilakukan oleh Sampurna dan Suatha (2010) dan riset kuantitas karkas dilakukan oleh Wiyatna (2007) serta aspek pakan oleh Sari dkk. (2016). Penilaian performa sapi yang dipelihara untuk keperluan pembibitan masih jarang dilakukan. Penilaiaan atas performa ternak penting untuk dilakukan untuk mengetahui keberhasilan kegiatan peternakan, baik untuk tujuan penggemukan maupun pembibitan. Oleh karena itu tujuan penelitian ini adalah untuk mengevaluasi pemberian pakan terhadap performa sapi Bali jantan yang dipelihara untuk pembibitan.

\section{MATERI DAN METODE}

Studi lapang di lakukan pada tanggal 1 September 2018 sampai dengan 30 November 2018 di Balai Pembibitan Ternak Unggul dan Hijauan Pakan Ternak Denpasar, Jl Raya Gilimanuk-Denpasar, Desa Pangyangan, Kecamatan Pekutatan, Kabupaten Jembrana, Provinsi Bali. Objek penelitian yang digunakan adalah sapi Bali jantan sebanyak 9 ekor, umur berkisar 1,6 sampai dengan 2,2 tahun dengan rata-rata bobot badan awal adalah sebesar $395 \pm$ $38,38 \mathrm{~kg}$. Data primer terdiri atas bobot sapi dan jumlah pemberian pakan sedangkan data sekunder berupa jenis pakan dan nilai nutrisinya. Alat yang digunakan berupa timbangan sapi, skop, dan bak plastik.

Jumlah pemberian pakan berupa hijauan rata-rata $9,68 \mathrm{~kg} / \mathrm{hari}$ dan konsensentrt $6 \mathrm{~kg} /$ hari. Pemberian pakan dilakukan dua kali dalam sehari yaitu pagi hari pukul 08.00 dengan pakan konsentrat 
diberikan terlebih dahulu, kemudian selang waktu 2 jam dilanjutkan pemberian pakan hijauan. Pemberian pakan yang kedua dilakukan pada pukul 14.00 dengan pemberian yang sama yaitu pakan konsentrat diberikan terlebih dahulu, kemudian diberikan pakan hijauan. Parameter pengamatan adalah konsumsi pakan yang dihitung dengan mengurangi pemberian dan sisa pakan yang diekspresikan dalam bentuk bahan kering (BK), pertambahan bobot badan harian $(\mathrm{PBBH})$ yang dihitung dari selisih bobot akhir dan bobot awal dibagi durasi pemeliharaan. Penimbangan bobot badan dilakukan secara mingguan. Data yang diperoleh diolah secara deskriptif menggunakan Microsoft Excel.

\section{HASIL DAN PEMBAHASAN}

Parameter pengamatan disajikan dalam Tabel 1. Jenis pakan yang diberikan dalam pemeliharaan berupa rumput dan juga diberikan pakan konsentrat komersial. Sapi Bali mengkomsumsi pakan sebesar $5,98 \mathrm{~kg}$ BK atau setara dengan $1,5 \%$ dari rata-rata bobot badannya. Asupan protein sebesar $811 \mathrm{~g} / \mathrm{hari}$ dan TDN 3,80 kg/hari PBBH sapi sebesar $0,5 \pm 0.08 \mathrm{~kg}$.

Tabel 1. Rata-rata konsumsi pakan, protein intake, TDN, dan PBBH sapi Bali Jantan pada periode pemeliharaan September - November 2018.

\begin{tabular}{lc}
\hline \multicolumn{1}{c}{ Parameter } & Nilai \\
\hline Konsumsi (kg BK/hari)* & 5,98 \\
Protein intake (g/hari)* & 811 \\
TDN (kg/hari)* & 3,80 \\
Bobot awal (kg) & $395 \pm 38,38$ \\
Bobot akhir (kg) & $408 \pm 39,12$ \\
PBBH (kg) & $0,5 \pm 0.08$ \\
\hline
\end{tabular}

Keterangan: *kalkulasi berdasarkan data sekunder nilai nutrisi pakan.

$\mathrm{BK}=$ bahan kering; $\mathrm{TDN}=$ total digestible nutrient

Nilai konsumsi pakan dalam studi lapang ini lebih rendah daripada konsumsi sapi Bali sebagaimana dilaporkan oleh Tahuk dan Dethan (2010). Dalam penelitian mereka, sapi Bali yang dipelihara oleh peternak mengkonsi pakan (BK) sekitar 2,57\%. Penelitian lainnya melaporkan bahwa sapi Bali jantan umur 2 tahun mengkonsumsi 3,6 \% (Sari dkk. 2016). Beberapa faktor yang mempengaruhi konsumsi pakan sapi adalah jenis pakan dan tujuan pemeliharaan. Hal yang dihindari dalam pemberian pakan sapi untuk tujuan reproduksi adalah kelebihan protein dan over-feeding karena berdampak negatif pada body condition score (Funston, R., 2006). Dalam penelitian ini asupan protein kasar sedikit lebih tinggi apabila dibandingkan dengan hasil penilitian Nanda, dkk (2014) yang melaporkan bahwa sapi Bali jantan mengkonsumsi protein kasar 420 g/hari samapi dengan 580 g/ekor. Perbedaan asupan protein tersebut disebabkan karena jenis dan kualitas pakan yang digunakan dalam studi ini lebih baik. PBBH sapi bali dalam studi ini setara dengan penelitian Tahuk dan Dethan (2010) namun lebih besar dibandingkan dengan daerah lain misalnya Nusa Tenggara Timur, PBBH sapi Bali umur 1 sampai dengan 3 tahun yang dipelihara oleh peternak berkisar 0,32 $\pm 0,16$ sampai 0,38 $\pm 0,19 \mathrm{~kg}$ (Tonbesi, dkk., 2009). Penentuan target PBBH dalam peternakan sapi dipengaruhi oleh tujuan pemeliharaan, atau dengan kata lain target $\mathrm{PBBH}$ untuk penggemukan berbeda dari pembibitan. Sapi Bali jantan dalam studi ini difungsikan sebagai pejantan untuk produksi semen. Untuk menghasilkan semen dalam jumlah cukup dan berkualitas maka diperlukan upaya kontrol terhadap manajemen pemeliharan terutama pakan. Kondisi yang 
sudah berjalan menujukkan bahwa kuantitas dan nutrisi pakan dapat dikatakan sudah memenuhi kebutuhan untuk pejantan.

\section{KESIMPULAN}

Sapi Bali dengan bobot awal 395,00 \pm $38,38 \mathrm{~kg} 60$ hari mengkonsumsi pakan sebesar 5,98 kg BK/ekor/hari, asupan protein kasar 0,81 kg/ekor/hari serta TDN $3,8 \mathrm{~kg}$ /ekor/hari. $\mathrm{PBBH}$ yang dihasilkan sebesar $0,5 \pm 0.08 \mathrm{~kg}$. Untuk tujuan pembitan, performa sapi berada dalam kisaran yang normal dan baik untuk pejantan sapi Bali

\section{DAFTAR PUSTAKA}

Astiti, N. M. A. G. (2018). Sapi Bali dan Pemasarannya. Denpasar: Warmadewa University Press.

Bandyopadhyay, M., Chakraborty, R., \& Raychaudhuri, U. (2007). A process for preparing a natural antioxidant enriched dairy products (sandesh). LWT-Food Sci. Technology, 40, 842-851.

Bindari, Y. R., Shrestha, S., Shrestha, N., \& Gaire, T. N. (2010). Effects of nutrition on reproduction- A review. Advances in Applied Science Research, 4(1), 421-429.

Funston, R. (2006). Nutrition and Reproduction Interactions. Proceedings Applied Reproductive Strategies in Beef Cattle October 3 and 4. Rapid City: South Dakota.

Kurnia sari, D. D. (2016). Pengaruh pakan tambahan berupa ampas tahu dan limbah bioetanol berbahan singkong (manihot utilissima) terhadap penampilan sapi bali (bos sondaicus). Buletin Peternakan, 40(2), 107-112. https://doi.org/10.21059/buletinpetern ak.v40i2.9191
Nanda, D. D., Purnomoadi, A., \& Nuswantara, L. (2014). Penampilan produksi sapi bali yang diberi pakan dengan berbagai level pelepah sawit. Agromedia, 32(2), 54-63.

Sampurna, I., \& Suatha, I. (2010). Pertumbuhan alometri dimensi panjang dan lingkar tubuh sapi bali jantan. Jurnal Veteriner, 11(1), 46-51.

Siswanto, M., Patmawati, N. W., Trinayani, N. N., Wandia, I. N., \& Puja, I. K. (2013). Penampilan reproduksi sapi bali pada peternakan intensif di instalasi pembibitan pulukan. Veterinary Science and Medicine Journal, 1(1), 11-15.

Tahuk, P., \& Dethan, A. (2010). Performance of bali bull in greenlot fattening by farmers when rainy season in Timor Island. Journal of the Indonesian Tropical Animal Agriculture, 35(4), 257-261. https://doi.org/10.14710/jitaa.35.4.257-261

Tonbesi, T. T., Ngadiyono, N., \& (Sumadi), S. (2012). The Potency estimation and performance of bali cattle in Timor Tengah Utara Regency, East Nusa Tenggara Province. Buletin Peternakan, 33(1), 30-39. https://doi.org/10.21059/buletinpetern ak.v33i1.132

Wiyatna, M. F. (2007). Perbandingan indek perdagingan sapi-sapi Indonesia (Sapi Bali, Madura,PO) dengan Sapi Australian Commercial Cross (ACC). Jurnal Ilmu Ternak Universitas Padjadjaran, 7(1), 22-25. https://doi.org/10.24198/JIT.V7I1.2227 